fuchsin stain for epoxy embedded tissue sections. Stain Technol 49:9-14

10. Sato T 1967 A modified method for lead staining of thin sections. J Electron Micros 16:133

11. Gil J, Marchevsky AM, Silage DA 1986 Methods in laboratory investigation Applications of computerized interactive morphometry in pathology: I Tracings and generation of graphic standards. Lab Invest 54:222-227

12. Underwood EE 1970 Quantitative Stereology. Addison-Wesley, Reading, MA

13. Weibel ER 1979 Practical Methods of Biological Morphometry. Stereological Methods. Academic Press, London

14. Gil J, Marchevsky AM, Jeanty H 1988 Septal thickness in human lungs assessed by computerized interactive morphometry. Lab Invest 58:466-472

15. Weibel ER 1963 Morphometry of the Human Lung. Springer-Verlag, Heidelberg

16. Groniowski J, Biczyskowa W 1962 Ultrastructure of the blood-air barrier of the neonatal human lungs, In: S. S. Breese (ed) Electron Microscopy. Proceedings of the 5th International Congress of Electron Microscopy Philadelphia, PA, p. ww5.

17. Gehr P, Bachofen M, Weibel ER 1978 The normal human lung: Ultrastructure and morphometric estimation of diffusion capacity. Respir Physiol 32:121140

18. Hodson WA, Alden ER, Woodrum DE 1977 Gas exchange in the developing lung. In: Hodson WA (ed) Development of the Lung. Marcel Dekker, Inc., New York, pp 469-496

19. Pessacq TP 1972 Considerations on the architectonics of alveolar blood vessels in the lung of the human embryo. Acta Anat 82:118-125

20. Cater G, Thiebeault DW, Beatty EC, Kilbride HW, Huntrakoon M 1989 Misalignment of lung vessels and alveolar capillary dysplasia: A cause of persistent pulmonary hypertension. J Pediatr 114:293-300

\title{
Announcement
}

\section{Annual Meeting of the Latin American Society for Pediatric Endocrinology}

The Third Annual Meeting of the Latin American Society for Pediatric Endocrinology will be held in Foz do Iguaçú, Paraná, Brazil, November 8-11, 1989.

For abstract and meeting information, contact Celina Fleury da Silveira, General Coordinator, Especifica S/C Ltda, Rua Augusta 2.516, cj 22, 01412 São Paulo, SP-Brasil, Telephone: (011) 55-881-7388, Telex: (11) 38372. 